\title{
On the Ethics of Psychometric Instruments Used in Leadership Development Programmes
}

\author{
Suze Wilson ${ }^{1} \cdot$ Hugh Lee ${ }^{2} \cdot$ Jackie Ford $^{3}$ (D) Nancy Harding ${ }^{4}$
}

Received: 14 September 2019 / Accepted: 18 April 2020 / Published online: 29 April 2020

(c) The Author(s) 2020

\begin{abstract}
The leadership development industry regularly claims to aid in developing effective, ethical leaders, using 360-degree psychometric assessments as key tools for so doing. This paper analyses the effects of such tools on those subjected to and subjectivised by them from a Foucauldian perspective. We argue that instead of encouraging ethical leadership such instruments inculcate practices and belief systems that perpetuate falsehoods, misrepresentations and inequalities. 'Followers' are presumed compliant, malleable beings needing leaders to determine what is in their interests. Such techniques pursue productivity and profitability, rather than ethical leadership. We examine the Multifactor Leadership Questionnaire, a widely used 360-degree tool that measures transformational leadership, as an illustrative case study to substantiate these criticisms.
\end{abstract}

Keywords 360 degree psychometric instruments $\cdot$ Foucault $\cdot$ Leadership development $\cdot$ Leadership ethics

\section{Introduction}

There is a global industry in leadership development (Kellerman 2018) earning business schools, management consultants and other providers between $\$ 14$ billion (Subramony et al. 2018) and $\$ 45$ billion a year (Day 2011). In addition to earning money, this industry appears to aim at improving the quality of leadership, so as to enact Ciulla's (1995) contention that 'good' leadership is both effective and ethical.

Jackie Ford

Jacqueline.ford@durham.ac.uk

Suze Wilson

S.E.Wilson@massey.ac.nz

Hugh Lee

Hugh.lee@kedgebs.com

Nancy Harding

h.n.harding@bath.ac.uk

1 Executive Development/School of Management, Massey University, Auckland, New Zealand

2 Kedge Business School, 680, Cours de La Libération, 33405 Talence Cedex, France

3 Durham University Business School, Mill Hill Lane, Durham DH1 3LB, UK

4 Head of Strategy \& Organisation Division, School of Management, University of Bath, Quarry Road, Bath BA2 7AY, UK
Although providers undoubtedly earn income, there is little evidence regarding leadership development programmes (LDPs) developing 'good' leaders. For starters, evaluation of the individual and/or organisational impact of LDPs is typically lacking in rigour, despite the enormous amount of money spent on such interventions (Avolio et al. 2010; Gabel et al. 2011; Jeyaraman et al. 2018; Whaley and Gillis 2018). Also of considerable concern is the common use of narrowly prescribed leader competencies, identities and behaviours, to which participants in LDPs are expected to conform themselves, coupled with such programmes being positioned as the preserve of those with 'special' qualities (Carroll et al. 2008; Gagnon and Collinson 2014; Probert and James 2011; Tourish et al. 2010). The kind of critical thinking that is foundational to the formation of ethical subjects (Foucault 2008, 2010; Ladkin 2018) is undermined when an LDP offers only prescriptive models of leadership. This is further exacerbated when leadership and its development is positioned as the domain of gifted elites, which seems unlikely to foster a concern to serve the greater good. Management education more generally has itself been the subject of extensive scholarly critique, with commentators identifying a lack of strong ethical focus and grounding (e.g. Ghoshal 2005; Mintzberg 2003; Mabey and Mahrhofer 2015).

This paper subjects one foundational aspect of many leadership development programmes, 360-degree feedback 
assessment tools, to critical analysis. Estimates suggest that by the end of the twentieth century the use of 360-degree tools was 'nearly universal' in Fortune 500 companies (Warech et al. 1998). Atwater and Waldman (1998) suggest that 'perhaps millions' have received 360-degree feedback (p. 421). In the twenty-first century their use has become 'almost ubiquitous in organizations of every type' (Day et al. 2014, p. 70). Markham et al. (2015) report the USbased Center for Creative Leadership alone used 360-degree instruments with more than 200,000 employees from 16,000 organizations between 1987 and 2010 (p. 958). Their use in leadership development is thus pervasive, even though such tools demand 'intense, comprehensive scrutiny' (Day 2001, p. 587) of those subjected to them.

As we explore briefly below, LDPs have recently been subjected to scholarly critique but, even so, research on the effects of 360-degree instruments is sparse relative to their widespread use (Day 2001; Day et al. 2014). Atwater and Waldman's attempt (1998) to edit a special edition on their use resulted in only two publishable papers. However, we do know these tools are "primarily intended to improve performance management' (Day 2001, p. 587) and that their 'focus is on identifying skills and competencies that are perceived by various sources to be effective or ineffective' (Day et al. 2014, p. 71). This indicates the principal concern of 360-degree feedback instruments to be a strongly instrumental orientation and not that of fostering ethical leadership. It is also the case that once a psychometric tool has secured professional credibility, through empirical testing and reporting of results in peer reviewed journals, it is commonplace for researchers to simply assume the tool itself can be used without further critical assessment (van Knippenberg and Sitkin 2013). Overall, then, 360-degree tools are widely used but rarely subjected to critical analysis. Whilst we recognize there are many technical questions that can be raised in relation to the efficacy of 360-degree feedback tools, our orientation here is to avoid using a paradigmatic lens which privileges positivist, objectivist and statistical ways of knowing. Rather, we seek to deploy philosophicallyinformed questioning to highlight the implicit but problematic assumptions and expose the unintended effects of such tools.

To do this, we subject 360-degree leadership development tools to a Foucauldian analysis and find their stated or strongly inferred objective of developing ethical leaders/ship implausible. Our illustrative case analysis - the Multi-factor Leadership Questionnaire (MLQ) which seeks to measure a leader's adherence to behaviours that Transformational Leadership theory commends to them-shows how such tools can actually promote highly unethical attitudes and behaviours.

These arguments are guided both by Foucault's distinction between morals and ethics and a Foucauldian understanding of power (and, thus, knowledge). This focuses on the processes by which individuals become subjects for whom the potential for ethical thought and action is routinely eroded through disciplining, normalising influences-and what can be done to address this (). We next introduce some of Foucault's key ideas on these matters, along with some initial insights about 360-degree feedback tools that emerge from this. After that, we examine key influences shaping leadership development practices and how 360-degree tools play into that before looking specifically at transformational leadership theory, which underpins the MLQ. As part of these discussions we highlight existing critical debates which help inform our thinking. Thereafter we examine the MLQ, explaining its development, prescriptions and governance arrangements before moving to offer our Foucauldian analysis of its subjectivating effects, underpinning moral code and genealogical conditions of emergence. We then consider the implications of our analysis before offering brief concluding thoughts.

\section{Insights from Foucault: And What They Imply About 360-Degree Instruments}

Foucault's interests, while seemingly diverse, coalesce around the need to critically analyse the varying and historically contingent ways in which persons come to believe they know the truth about themselves, thereby giving rise to practices and processes of subjectivation which have both productive and repressive potential and effects (e.g. Foucault 1982; Mennicken and Miller 2014; Taylor 2011a). Philosophical and ethical effort, for Foucault, means questioning the kinds of subjects sought, or whose existence is possible, given the historically specific character of the disciplining, normalising "games of truth" (Foucault 1990, p. 6) and power/knowledge mechanisms and apparatus in which they are enmeshed (Mennicken and Miller 2014; Taylor 2011a). This involves analysis of "the practices by which individuals were led to focus their attention on themselves, to decipher, recognise, and acknowledge themselves as subjects", a process Foucault argued is shaped by expert discourses which claim to provide important truths and in accordance with which subjects are expected to conform their selves (Foucault 1990, p. 5). Drawing on these understandings, our contention is that 360-degree instruments which deploy prescriptive standards as to what constitutes effective leadership can give rise to conformity-inducing processes of subjectivation. Their prescriptions, which both reflect and reinforce contemporary understandings of leadership, claim to help participants to bring themselves to a state of excellence but in so doing elicit harmful and ethically troubling effects.

The moral domain, for Foucault, concerns the historically contingent normalizing, disciplining ensemble 
of policies, rules, laws, principles, beliefs, theories and practices which seek, with greater or lesser precision and consistency and with greater or lesser degrees of compliance, to establish and sanction what actions and ways of being are socially legitimated as morally correct or incorrect (Foucault 1990). These are prescribed for and to individuals, typically by those claiming expertise and/ or authority. These experts seek to determine what are to be regarded as morally acceptable acts, practices, policies and procedures to follow (Foucault 1990, p. 25). Morality is therefore the historically contingent and hence ultimately arbitrary domain of the moral code or codes qua prescriptions that exist independently of individual subjects, but which work upon and within subjects and to which subjects may defer or resist (). Consequently, when 360-degree instruments prescribe specific behaviours as constituting 'good' leadership these effectively constitute a 'moral code' to which participants are expected to submit themselves without question.

'Ethics', in contrast, involves formulating and acting in accordance with one's own critically-informed assessment as to what constitutes desirable and proper conduct. For Foucault, ethics refers to the self-constituting, self-disciplining practices by which a subject works on itself to adopt "a certain mode of being that will serve as his (sic) moral goal" (1990, p. 28). The domain of ethics encompasses techniques and practices of self-knowledge, self-nurture, self-care, selfdiscipline and self-transformation. Here, subjects seek to bring themselves into new relationships with themselves, others and normalizing discourses, and thus may or may not resist, comply with or formulate their own normative moral codes.

Foucault argued a subject's capacity to exercise such ethical agency emerges from practices and techniques that he labelled 'care of the self', the purpose of which is "to work out, to transform one's self, and attain a certain mode of being" (Foucault 1986, p. 2) that vivifies one's best, even transcendent, qualities (Ladkin 2018). This implies that becoming an ethical leader must involve both critically evaluating what is ascribed to and prescribed for leaders and engaging in self-directed efforts to constitute oneself as an ethical being (Robinson n.d.; Foucault 1990; Ladkin 2018).

Importantly for Foucault, neither domain (morals or ethics) has absolute control over subjects: freedom is always conditional and never absolute, and subjects are not merely products of externally imposed constraints and demands (Crane et al. 2008; Foucault 1990, 2008, 2010). Consequently, 360-degree feedback processes routinely function in ways that vitiate such processes of ethical self-making, instead inciting the development of docile adherents to a prescribed, and inherently problematic, morality. However, as neither morality nor ethics has complete control over subjects then increased awareness of the problems involved in
360- degree instruments can aid in emphasizing the importance of ethical self-making.

That said, Foucault argues that the process of constituting oneself as an ethical subject is conditioned by the relations of power (and thus knowledge) in which the subject is enmeshed. Thus, he contends that individual agency alone, though neutered only in extreme circumstances, is also never sovereign (Foucault 1990). Rather, we are constantly surrounded by disciplinary forces that both prescribe for, and instil within us, priorities and ambitions regarding what manner of self we should expect or desire to be and what purposes, practices and actions we ought to adopt (Foucault 1977). Accordingly, Foucault proposes that if we are to constitute ourselves as agentic, ethical beings we must critically interrogate and be willing to reject or modify such expectations and desires (Foucault 1990). We argue, consequently, that 360-degree feedback processes are routinely formulated in ways that generate intensive, prescriptive, disciplinary effects and, moreover, discourage critical questioning of those prescriptions, thus inhibiting rather than enabling the development of ethical leaders. This, we argue, needs to change. We later extend this critique to the specific prescriptions of the MLQ, as an illustrative case, showing that what it commends to leaders is also substantively problematic.

However, discourses and their associated practices are never complete or absolute and, crucially, depend on an ontological potential for freedom that enables engagement in practices of self-analysis and self-formation (Crane et al. 2008; May 2011; Taylor 2011a). Such efforts may embrace, adapt or resist normalised expectations of (moral) discourses that claim to speak the truth about our nature, character, desires and capabilities (Crane et al. 2008; Foucault 1990, 2008, 2010). The ethical response to such expectations and prescriptions, according to Foucault, involves a self working upon itself to craft an "aesthetics of existence" (1990, p. 12) that, while informed by normalising discourses, comes nonetheless to possess a singularity of knowledge, truth, experience and being that both enables and comprises its very constitution as an ethical being (Foucault 1986, 1990, 2008). By subjecting 360-degree instruments to critique informed by such understandings we demonstrate both the need for, and potential foundations of, ethically-rooted self-making practices that could be used in leadership development, better to foster 'good' leadership.

Our Foucauldian reading of 360-degree instruments conceptualises them as both mechanisms of power/knowledge and as normalising discourses. They serve neoliberal capitalism by seeking to subjectivate those who use them as agents of growth-based capitalism, with consequential negative effects in terms of the developing leader's capacity for ethical agency. 360-degree tools are, also, resources for self-making efforts, holding considerable appeal to middle class neoliberal capitalist subjects in particular because 
they appear to offer a route to 'success' on terms valued under capitalism. They are packaged in ways that are broadly consistent in form and purpose with a multiplicity of selfmaking practices, available for purchase, through which predominantly middle-class contemporary subjects come to see their lives and selves as entrepreneurial projects (Scharff 2015). For all these reasons, then, despite the reservations we have about such instruments it is important to acknowledge they have wide-spread appeal. We therefore return to this issue in the final part of the paper where we consider the implications of our analysis.

Our Foucauldian lens highlights four further key insights of general relevance to understanding 360-degree tools, which also underpin our case study analysis of the subjectivating effects of the MLQ. First, we see 360-feedback tools as being akin to a clinical examination in which subjects are expected to speak (i.e. confess) of themselves only using terms prescribed by experts as relevant and desirable (Foucault 1978, 1989), thereby constraining the self-making process. Second, we view them as disciplining and subjectivating mechanisms of panoptic design and effects, soliciting a docile subject who internalises the encircling feedback given from those below (subordinates), above (superordinates) and alongside (peers), who are themselves compelled to focus their commentary on matters that experts (the designers of 360-degree tools) deem worthy of consideration (Foucault 1977).

Third, we understand these tools as constituting an apparatus of governmentality, a means to impersonally administer the 'conduct of conduct' (Gordon 1991, p. 2) through, for example, facilitating the collation of data that can be used to develop policy and practices to 'optimise' the leader population, thus subjecting leaders to pervasive surveillance that normalises, disciplines and inhibits their potential to develop ethical agency. Finally, however, we also understand these instruments as comprising what Foucault termed "techniques of the self" (Foucault 1990, p. 11), meaning they have potential to contribute to the ethical practice of a self working on itself (Foucault 1990, 2008, 2010) if formulated and operationalised in ways that foster such self-constituting practices. This potential is severely circumscribed by current practices which are rooted within a specifically capitalist morality and seek to produce docile leaders who will, in turn, produce similarly docile and disciplined workerfollowers. Consequently, these instruments currently pose a threat to the development of ethical leaders because not only are they a moralising disciplinary practice that is itself ethically unsound but also their specific prescriptions, as shown later in our analysis of the MLQ, can also be ethically problematic.

Overall, our engagement with Foucault enables us to move beyond a merely technical analysis of psychometric instruments to, instead, illuminate the complex and troubling effects of such tools on those subjected to and subjectivised by them. Using the MLQ as our illustrative example we contend that the subject invoked via its prescriptions is not ethically meritorious. In doing this we also situate such practices within a historically specific version of 'morality' that serves and sanctions contemporary capitalism. Identifying these various limitations is, we suggest, the necessary first step toward overcoming them or, at least, mitigating their potential for harm. However, to help first explain how and why these various problems have become such pervasive features of leadership development we next turn to examine the key theoretical influences on that industry, before examining transformational leadership theory, which underpins the MLQ, specifically. As part of this we highlight existing critiques which inform our thinking and which we seek to build on.

\section{Leadership Development: A Production Line for Building Heroes?}

Many leadership development programmes are today guided by transformational and other closely related heroic leadership theories as the 'ideal' to which participants are encouraged to aspire (Day 2011; Day et al. 2014; Harrison 2017; Pinnington 2011). The continuing dominance of heroic approaches is supported by empirical research using quantitative methods to assess correlations between leader characteristics and behaviours and the positive effects on followers described in these theories, often using very similar survey questions to those in 360-degree instruments (e.g. Braun et al. 2013; Wang and Howell 2012; Wong et al. 2010). These orienting frames of reference means LDPs typically emphasize enhancing leaders' capacity to maximise organisational outcomes, results which are said to depend on participants enacting the prescriptions drawn from transformational or other heroic notions of leadership (Mabey 2013; Larsson et al. 2019; Tourish et al. 2010).

A range of more expansive models of leadership have recently emerged which challenge the desirability of the heroic, individual-based theories (Bradford and Leberman 2017; Crevani et al. 2010; Gagnon et al. 2012; Ladkin 2008; Uhl-Bien 2006). This has led to more embodied, arts-based and/or identity-focussed approaches to leadership development (Adler 2006; Carroll and Nicholson 2014; Nicholson and Carroll 2013; Sutherland 2013; Taylor and Ladkin 2009), though these remain very much at the margin (Larsson et al. 2019).

Theoretical innovation in mainstream leadership studies proceeds incrementally, with most empirical studies simply accepting the basic validity of the selected theory and/or its associated instruments (Hunter et al. 2007; Mabey 2013; van Knippenberg and Sitkin 2013; Wilson 2016). Despite this, 
Jackson and Parry (2011, p. 7) argue that "hard evidence about the impact of leadership is surprisingly and tantalizingly hard to find". Notwithstanding such a tentative evidence base, many heroic models have been translated into psychometric tests used in recruitment and training with the key elements of, notably, transformational leadership now constituting a widely sought-after standard for effective organisational leadership (Bolden et al. 2011; Ford et al. 2008; Jackson and Parry 2011).

Diochon and Nizet (2019) discussed the ubiquity of 360-degree psychometric assessment in leadership development programmes. Advocates claim such tools assess individuals' leadership styles and reveal their influence upon followers. Because 360-degree tools typically compare an individual leader to a given leadership theory, prescriptive norms or standards against which 'good' leaders are presumed to score well are built into the design of such instruments: a low score is thus taken to indicate suboptimal or even ineffective leadership. LDP participants are required to rate themselves against a series of factors and then ask colleagues (bosses, peers and 'direct reports') to rate them using the same factors. The ratings are often aggregated by 360-degree instruments (Fleenor et al. 2010; Markham et al. 2015).

Such processes often have two stages, as is the case for the MLQ: completion of the rating scale and feedback. In Stage One participants are asked to rate themselves and request their boss, peers and direct report to rate them anonymously against a series of statements which claim to measure effective and ineffective leadership behaviours, approaches or styles. Often a Likert scale is used, allowing raters to signal the degree of the ratees' compliance with any given question or statement. In Stage Two written or verbal feedback is given about the results achieved. Numeric scores may be used to inform individuals of the quality of their leadership relative to the presumed 'ideal' standard and to identify areas for improvement. High scores on the transformational leadership factors such as are measured by the MLQ are taken to indicate the subject is a 'good' leader in both senses of the word. Firstly, they evoke superior performance in followers and so are good at the arts of leadership. Secondly, they are ethically good because followers benefit directly (flourishing under good leaders), and society benefits indirectly (higher productivity resulting from leaders' influence).

Verbal feedback frequently involves one-to-one meetings between trainer and participant. Participants are encouraged to talk at length and in depth about themselves, but always in relation to the findings of the 360-degree feedback. Leadership development programs thus claim to help participants identify their limitations as leaders and provide prescriptive guidance on how to overcome them and, in so doing, become 'good' leaders. The 360-degree instrument plays a vital part in this because it measures baseline performance prior to the developmental experience and any changes can then be identified via a subsequent re-testing process.

There are concerns about the subjectivity inherent in such tools: peers, direct reports and managers tend to define effectiveness in different ways (Hooijberg and Choi 2000). Fleenor et al's (2010) review suggests assessments vary according to raters' leadership schemas, personalities and motivations to carry out the task and the quality of their interactions with the ratee. That is, judgement of leadership effectiveness may be subjective (Day et al. 2014). It is not therefore surprising that the (typical) aggregation of feedback from the range of assessors is questionable (Markham et al. 2015). This problem is further exacerbated, we would suggest, by drawing potentially influential conclusions about individuals from a very small number of respondents, typically between six and 15 in total. Furthermore, an individual's acceptance of 360-degree feedback is directly related to how favourable the feedback is: a poor rating is likely to be rebutted; a high rating accepted willingly (Facteau et al. 1998). Nevertheless, 360-degree instruments are used extensively, as the statistics presented above demonstrate. Overall, management careers are widely thought to depend on organizational leaders becoming transformational, charismatic, visionary and authentic: LDPs both seek to fulfil and reinforce such expectations, using 360-degree feedback instruments as key 'tools of trade'.

Critically-oriented leadership scholars, however, have exposed a multiplicity of problems with such approaches. The foundational problem of interest in both political and ethical terms pertains to notions of leadership that implicitly render some special and others abject (Gemmill and Oakley 1992). The masculinist norms embedded in heroic models of leadership, such as the emphasis given to agentic rather than communal qualities, exacerbates this basic problem along gendered lines (e.g. Ford et al. 2008; Eagly 2007; Sinclair 1998).

These ideals create a standard for what constitutes a leader which is infused with patriarchal beliefs and norms. More recent analyses have now shown that these ideals also function in ways that serve to sustain white power and privilege and foster colonizing ambitions of mastery over all aspects of life (Liu 2019, 2020; Liu and Baker 2016). This arises through the implicit association of what is seen as 'leadership' with white values, beliefs and interests, thus further expanding the grounds for objecting to these dominant ideals and their underpinning assumptions.

Such problems are an effect of the ideologically-based reasoning that routinely saturates studies of leadership, in which leadership is simply assumed to be natural, ethical and a potent source of improved outcomes (Alvesson and Karreman 2016; Sinclair 2007; Wilson 2016). These essentialist epistemological assumptions, combined with the pervasive 
use of a natural sciences orientation to studying leadership, foster a lack of reflexivity that all but assures the sustained focus on heroic (ie gendered, raced) notions of leadership by most scholars (Alvesson 1996; Collinson 2011; Wilson 2016). In a social context in which 'white supremacist capitalist patriarchy' (hooks, in Liu 2020) constitutes the dominant ideological and structural paradigm, the moral authority of leadership science largely serves to sanction and validate the enormous appeal of heroic models to managers seeking such mastery in order to secure greater profitability and advance their own careers.

In bringing a critical lens to LDPs, scholars have identified the difficulties participants commonly face in securing a leader identity. They also highlight the often subtle but influential techniques through which such programmes often nonetheless solicit the formation of that identity in heroic, masterful terms (e.g. Caroll and Nicholson 2014; Gagnon and Collinson 2014; Nicholson and Carroll 2013). As noted earlier, 360-degree instruments are commonly used as part of such efforts.

To help in overcoming these concerns critical scholars have highlighted the need in LDPs, and in leadership education more generally, for much greater attention to issues of context, to power dynamics and issues of resistance and dissent-including what arises between participants and facilitators - and to understanding the complex nature of identity work (Carroll and Nicholson 2014; Collinson and Tourish 2015; Diochon and Nizet 2019; Edwards et al. 2013; Gagnon and Collinson 2014; Nicholson and Carroll 2013). In this paper, we extend existing critical analyses of leadership theory and LDPs via a Foucauldian reading that draws out the ethical implications for a leader's identity that can come from engaging in the use of 360-degree tools, using the MLQ as our illustrative case. We thus offer a deep, critically informed, dive into a key practice of the leadership development industry, the use of 360-degree feedback instruments, to contribute to the body of evidence that explores how ethically 'good' leadership might, in fact, be developed.

We next highlight some key criticisms that can be levelled specifically at transformational leadership theory. We do this because if these criticisms hold true of transformational leadership theory, the same concerns logically flow through into the MLQ psychometric tool which claims to measure compliance with its prescriptions ${ }^{1}$ : we later examine the MLQ to highlight problems with such tools more generally.

\footnotetext{
1 https://www.mindgarden.com/16-multifactor-leadership-questionna ire; accessed 29th November 2019.
}

\section{Transformational Leadership Theory and the MLQ: A Critical Review}

Transformational leadership theory has core concepts and constructs underpinning its 'full range leadership model' (Avolio and Bass 1991; Bass 1995, 1999; Bass and Riggio 2006) that divide leadership into two aspects: transformational and transactional. The core constructs have been translated into psychometric and other developmental tools and presented as a direct link between theory and practitioner development (Antonakis et al. 2003; Avolio et al. 1999a, b). A substantial evidence base is claimed for transformational leadership theory and, by implication, the MLQ (e.g. Braun et al. 2013; Wang and Howell 2012; Wong et al. 2010). Given its extensive use in leadership research and development most empirical studies accept the validity of the theory and/or its associated instruments (Hunter et al. 2007; Mabey 2013).

Proponents of transformational leadership regard such leadership as synonymous with change for good (Avery 2004; Bass 1985; Jackson and Parry 2011), and transformational leaders are held to possess 'charisma', 'vision' and 'authenticity' (Jackson and Parry 2011; Huczynski and Buchanan 2006). They are deemed capable of achieving outstanding results and bringing about dramatic changes in purpose, strategy, values and culture (e.g. Avolio and Bass 1995; Avolio et al. 1999a, b; Avolio and Luthans 2003; Bass 1985; Bass and Riggio 2006), eliciting commitment, effort and personal growth from followers (Avolio and Gardner 2005; Bass 1985).

The MLQ is a particularly influential 360-degree feedback instrument, directly tied to Bass and colleagues' development of transformational leadership theory ${ }^{2}$. It is discussed in many studies of transformational leadership and used widely for leadership assessment and development purposes (Jackson and Parry 2011; Van Knippenberg and Sitkin 2013). Because of its influential status, we analyse it as an illustrative example of the kinds of problems to which such tools are prey.

The MLQ has undergone various iterations (Avolio and Bass 1991; Avolio et al. 1999a, b). Its developers claim it measures and helps improve leadership styles and recommend its use in research studying correlations between transformational leadership and outcomes, including organizational/worker performance and satisfaction ${ }^{3}$ (Delaney and Spoelstra 2019). This is made possible, it is claimed, because of the inclusion within the MLQ of three outcome

\footnotetext{
${ }^{2}$ https://www.mindgarden.com/16-multifactor-leadership-questionna ire\#horizontalTab6; accessed 29th November 2019.

${ }^{3}$ https://www.mindgarden.com/16-multifactor-leadership-questionna ire; accessed 29th November 2019.
} 
criteria: followers' extra effort, the effectiveness of the leader's behaviour, and followers' satisfaction (Rowold 2005).

The MLQ instrument is based on studies by Bass and colleagues that asked chief executives, senior and junior managers to describe attributes of transactional and transformational leaders (Lowe et al. 1996). The resulting 142 items were reduced to 73 to form the basis of the first MLQ (Bass and Avolio 1994). It originally comprised five scales, three defined as characteristic of transformational leadership ('charisma', 'individualized consideration' and 'intellectual stimulation') and two relating to transactional leadership ('contingent reward' and 'management by exception') (Lowe et al. 1996). Further research identified nine factors, five of which assess charismatic-transformational leadership, three transactional leadership, and one assessing what Bass and Avolio (1994) termed as 'laissez-faire' (or non-) leadership. The five charismatic-transformational leadership factors are 'idealised influence' (attributed); 'idealised influence' (behaviour); 'inspirational motivation'; 'individualised consideration'; and 'intellectual stimulation'. The transactional factors are 'contingent reward'; and 'active' and 'passive' forms of 'management by exception' (Bass 1999; Bass and Riggio 2006), together with laissez-faire or, the absence of leadership (van Knippenberg and Sitkin 2013, p. 12). Different MLQ users may collapse complementary factors into each other (Van Knippenberg and Sitkin 2013).

Major critiques now question the fundamental assumptions, constructs and effects of Bass and colleagues' account of transformational leadership (e.g. Alvesson and Kärreman 2016; Tourish 2013; Wilson 2016). Van Knippenberg and Sitkin (2013) show that the MLQ's factors are not based on sound scientific research but on a grounded taxonomy that, firstly, presumes what factors constitute good leadership and then, secondly, sets out to look for these in practice. This is fundamentally logically flawed: 'you cannot define a concept in terms of its effects and such a definition would disqualify the concept from studying its effects' (van Knippenberg and Sitkin 2013, p. 11). They argue further that research into the MLQ and similar instruments is hindered, if not also fundamentally flawed, by a lack of conceptual definitions and assumptions that a group of behaviours coheres simply because of being clustered under a common label. Finally, they show the circularity of the research supporting these instruments: they define leadership in terms of what is thought to have desirable effects on followers, then define effective leaders as those portraying those characteristics. So 'the MLQ and similar instruments study the effectiveness of leadership that is defined a priori as effective' (Knippenberg and van Sitkin 2013, p. 15).

Such challenges to the scientific utility and veracity of transformational leadership, and thus the MLQ, have not damaged the MLQ's influence upon both theory and practice. Each year many thousands of people are assessed using this or similar 360-degree instruments (Atwater and Waldman 1998; Day et al. 2014; Markham et al. 2015; Warech et al. 1998). Regardless of their conceptual and logical weaknesses these tools have real world effects.

Transformational leadership theory and by logical implication the MLQ, positions followers as passive respondents to the heroic, exceptional individuals that leaders are told they must and should be. This is far removed from the mundane realities that constitute much organisational effort (Ford and Harding 2007; Meindl et al. 1985). The glossing over of important complexities, paradoxes and ambiguities in leadership practice ignores the realities of organizations as sites of ongoing struggle, where the dialectic dynamics of consent/dissent, control/resistance and men/women are continuously in tension (Carroll and Nicholson 2014; Collinson 2005, 2006; Sinclair 2007) and where the construction of leader or follower identities is fluid, effort-full and often tenuous (Alvesson and Sveningsson 2003; Ford et al. 2008; Nicholson and Carroll 2013). Its expectations impose great pressures on anyone striving to become 'transformational' (Ford et al. 2008; Sinclair 2007), encouraging hubris in those who see themselves in such grandiose terms (Kellerman 2004; Tourish 2013).

Consequently, there are serious concerns about its failure to grasp the realities of practice and critical analysis identifies transformational, and other 'new leadership' theories, as a source of actual harm. This is therefore immoral, not only because it risks serious psychic harm (Ford and Harding 2011), but also because it imposes on leaders a requirement to achieve something impossible: Ciulla (2013) found that even Nelson Mandela's efforts do not meet the expectations advocated by proponents of 'new leadership'. Transformational leadership theory is, quite evidently, ethically problematic.

The theory offers seductive, typically masculine, subject positions, locating managers within discourses whose norms emphasise the necessity of being attractive, powerful and compelling individuals, miraculously free from human frailties (Calas and Smircich 1991; Ford et al. 2008; Ford and Harding 2018; Larsson et al. 2019; Sinclair 2007; Wilson 2016). In many ways transformational leadership theory resembles faith-based regimes in which followers (the damned) are converted into leaders (the saved) by way of the leader's influence (Delaney and Spoelstra 2019; Wilson 2016). Its grandiose and harmful fantasies (Ford et al. 2008; Tourish 2013; Wilson 2016) encourage a distorting, narcissistic self-image that harms decision making, suppresses debate and fosters cult-like organisational cultures (Alvesson 2013; Ford et al. 2008; Tourish 2013).

Transformational leadership theory's prescriptions for practice aim to ensure leaders have such influence over followers that followers are themselves 'transformed', not into beings of their own choosing but, rather, into leaders. The 
Table 1 Constructs and behaviours in transformational leadership theory which inform 360-degree instruments such as the MLQ

\begin{tabular}{|c|c|}
\hline Construct & Behaviours \\
\hline $\begin{array}{l}\text { Idealized influence (NB this includes } \\
\text { the two subscales of attributes and } \\
\text { behaviour) }\end{array}$ & $\begin{array}{l}\text { Leaders have: confidence, values, beliefs, and sense of mission; are charismatic; possess personal } \\
\text { power; focus on 'higher-order ideals and ethics' (Antonakis et al. 2003, p. 264), 'instil pride, } \\
\text { respect and trust' in followers (van Knippenberg and Sitkin 2013, p. 5) } \\
\text { Idealised influence (attributes): charisma is attributed to leaders. Positive characteristics (leaders' } \\
\text { focus on higher-order ideals/values) evoke closer emotional ties in followers } \\
\text { Idealised influence (behaviour): leaders emphasise and enact a collective sense of mission/values }\end{array}$ \\
\hline Inspirational motivation & $\begin{array}{l}\text { Leaders 'energize' followers through 'projecting an idealized vision' and communicating confidence } \\
\text { in its achievement (Antonakis et al. 2003, pp. 264-265; van Knippenberg and Sitkin 2013) }\end{array}$ \\
\hline Intellectual stimulation & $\begin{array}{l}\text { Leaders encourage followers to 'think creatively and find solutions to difficult problems' (Antonakis } \\
\text { et al. 2003, p. 264) }\end{array}$ \\
\hline Individualised consideration & $\begin{array}{l}\text { Leaders are active in 'advising, supporting and paying attention to the individual needs of followers, } \\
\text { encouraging their development and self-actualization' (Antonakis et al. 2003, p, 265) }\end{array}$ \\
\hline Contingent reward & $\begin{array}{l}\text { Leaders focus on clearly defined tasks, and reward followers (materially or psychologically) for } \\
\text { fulfilling them (Antonakis et al. 2003; Antonakis and House 2002) }\end{array}$ \\
\hline Active manage-ment by excep-tion & $\begin{array}{l}\text { Leaders monitor followers for deviations from rules/standards; correcting deviations (Antonakis et al. } \\
\text { 2003; Antonakis and House 2002) }\end{array}$ \\
\hline Passive manage-ment by excep-tion & $\begin{array}{l}\text { Leaders intervene only after failure to meet standards or problems arising (Antonakis et al. 2003; } \\
\text { Antonakis and House 2002) }\end{array}$ \\
\hline Laissez faire & $\begin{array}{l}\text { Absence of or non- leadership: responsibilities are abdicated, decisions delayed, no feedback given. } \\
\text { (Antonakis et al. 2003; van Knippenberg and Sitkin 2013) }\end{array}$ \\
\hline
\end{tabular}

form and scope of this influence allegedly serves the interests of all (Burns 1977; Bass 1985), despite its disturbingly clone-like character (Wilson 2016). Moreover, the behaviours it seeks and sanctions are imbued with race- class- and gender-based norms which, as discussed earlier, privilege whiteness, neoliberal middle class norms and behaviours and socially dominant forms of masculinity (Ford et al. 2008; Liu and Baker 2016; Liu 2020; Sinclair 1998). Its prescriptions constitute a form of 'second-generation bias' that affects an individual's ability to form a leader identity and be accepted by others as such and, in so doing, function as a mechanism through which systemic inequalities are reproduced and transmitted (Eagly and Chin 2010; Collinson 2003; Sinclair 1998; Stead and Elliot 2009).

Consequently, the behaviours and impacts sought from transformational leaders can be broadly understood as a colonizing discourse of mastery over others which, in turn, has the overall effect of reinforcing and serving 'imperialist white supremacist capitalist patriarchy' (hooks, cited in Liu 2020). Instead of constituting a means for transforming existing systems of exploitation, domination and oppression, ironically the prescriptions offered by transformational leadership function to reinforce those very systems (Ford et al. 2008; Grint et al. 2016; Liu 2020; Wilson 2016). The exclusion from leadership of those already missing or marginalised is thus sustained, with those whose identities intersect these markers facing a compounded level of disadvantage (Lugar et al. 2019; Liu 2020). Notwithstanding these concerns, a discourse of mastery has potent appeal to those aspiring to render themselves into 'success stories' as defined by dominant ways of thinking, meaning there is a plethora of candidates desirous of becoming transformational leaders and all that that implies for career success.

Responding to such charges, influential theorists such as Bass and Steidlmeier (1999) have drawn a distinction between 'pseudo-transformational' and 'authentic transformational' leaders, a distinction itself questioned as ethically dangerous (Ford and Harding 2011, 2018). Bass and Steidlmeier (1999) imply that occasional 'bad apples' amongst transformational leaders can be identified and protest that transformational leadership offers a 'socialised' model of influence which inhibits leaders from doing harm to their followers. However, such responses fail to acknowledge the ethical problems implicit in encouraging managers to seek (and perhaps secure) such profound, transformative changes in employees' sense of self and world view.

\section{The Mlqs Formation, Governance and Prescriptions}

Table 1 provides Bass (1985) and colleagues' summary of the transformational, transactional and non-leadership dimensions that have been translated into psychometric and other developmental tools, such as the MLQ (Avolio et al. 1999a, b; Antonakis et al. 2003; www.mindgarden.com).

The MLQ claims to measure individuals against these factors, helping "leaders discover how they measure up in their own eyes and in the eyes of those with whom they work" with changes "measured through a retesting program 
to track changes in leadership style". ${ }^{4}$ It develops profiles that compare individuals against an ideal. Those not reaching the ideal are given advice for how to better conform with the ideal.

Mind Garden, Inc, founded by Robb Most, PhD, in 1994, ${ }^{5}$ credits 'Profs Bernard Bass (deceased) and Bruce Avolio' as copyright owners of the MLQ while Mind Garden claims trademark of the tool, which it promotes for assessment, development and research. ${ }^{6}$ Mind Garden claims on its website (website www.mindgarden.com) that transformational leadership can be measured by the MLQ thus:

The MLQ measures the concepts of transformational and transactional leadership. The MLQ has undergone various revisions over the years and had achieved a set of items that are clear, behaviorally based, and so central to the concepts that there are only four items per concept (scale) and yet the MLQ consistently shows excellent validity and prediction of organizational performance. $^{7}$

Copyright/trademark restrictions prevent us from directly itemising and discussing here the questions contained in what the Mind Garden website indicates is its current version of the MLQ, version $5 \mathrm{x} .{ }^{8}$ Indeed when researchers secure authority to use the tool, through paying a license fee to Mind Garden, they likewise face restrictions in how their results are reported, thereby protecting Mind Garden's intellectual property rights over the MLQ instrument itself. ${ }^{9}$ Mind Garden permits only 3 specified sample questions to be disclosed, claiming that this is to protect "the integrity and value" of the MLQ. ${ }^{10}$ Whilst we appreciate that such

\footnotetext{
${ }^{4}$ https://www.mindgarden.com/16-multifactor-leadership-questionna ire, accessed 28th November 2019).

5 https://www.mindgarden.com/content/4-about-us\#horizontalTab2

${ }^{6}$ https://www.mindgarden.com/16-multifactor-leadership-questionna ire, accessed 27/11/2019.

7 https://www.mindgarden.com/16-multifactor-leadership-questionna ire\#horizontalTab6, accessed 27/11/2019.

8 A google search for 'free MLQ' generates a range of documents that appear to be some version of the MLQ, however as we cannot determine their copyright status we have not quoted or cited them here. We are also aware that Peter Northhouse's influential textbook Leadership: Theory and Practice, now in its 8th edition, did include 9 items of the MLQ in earlier editions. However where this occurs in the $6^{\text {th }}$ edition it is made clear that 'further reproduction is prohibited without the publisher's written consent" (Northouse 2013, p. 213), meaning Mind Garden, hence we do not quote it directly either.

9 https://www.mindgarden.com/multifactor-leadership-questionna ire/227-mlq-license-to-reproduce.html and https://www.mindgarden .com/multifactor-leadership-questionnaire/226-mlq-remote-onlin e-survey-license.html; accessed 27th November 2019.

10 https://www.mindgarden.com/16-multifactor-leadership-quest
} ionnaire\#horizontalTab2; accessed 27th November 2019. restrictions protect the commercial value of the instrument it is less obvious how preventing scrutiny preserves integrity.

The development of the MLQ and, of course, transformational leadership theory itself, has been the subject of extensive scholarly debate and evaluation, some of which we reviewed earlier. Mind Garden also goes to the effort of listing multiple studies on its website, to provide evidential support for the MLQ's credibility. ${ }^{11}$ However, positioning of the MLQ as constituting knowledge which today resides in an opaque domain inhabited by only a select few whose utterances are beyond question is disconcertingly reminiscent of how the medieval church, pre Luther, saw the role of the clergy and their exclusive right to read and interpret the bible (Kolb 1987).

Given that Foucault commends us to question everything, these governing conditions as to who may see and thereby question the 'truth' according to the MLQ hardly fosters ethical agency in those subjected to its prescriptions. We willingly acknowledge that Mind Garden is not unusual in seeking to protect its intellectual property via such measures and its approach is - both merely and worryingly-standard industry practice for controlling the use of psychometric tools. Given the personal and sensitive nature of the knowledge obtained about subjects completing 360-degree instruments, the ubiquity of their use and their potentially significant effects on subjects' careers and well-being, the lack of transparency of these tools and the uses to which they are put is disquieting.

It is due to these governing conditions that in Table 1, rather than quoting directly from the MLQ itself, we set out the key constructs of transformational leadership theory and associated elaborations of such informed by discussion and findings in relevant studies that used the current or earlier versions of the MLQ, or which discuss the core constructs of transformational leadership theory (e.g. Antonakis et al 2003; Antonakis and House 2002; van Knippenberg and Sitkin (2013).

Mind Garden explains that the MLQ describes someone's leadership style through assessing responses to 45 questions. ${ }^{12}$ It can be used for self-assessment but is recommended as part of 360-degree feedback by colleagues. A marketing feature is that it takes only $15 \mathrm{~min}$ to complete and the subsequent feedback report "makes personal to individuals how they relate on the key factors that set truly exceptional leaders apart from marginal ones". ${ }^{13}$

\footnotetext{
$11 \mathrm{https}: / / \mathrm{ww}$ w.mindgarden.com/16-multifactor-leadership-quest ionnaire\#horizontalTab5; accessed 29th November 2019.

12 https://www.mindgarden.com/16-multifactor-leadership-quest ionnaire\#horizontalTab6, accessed 29th November 2019).

13 https://www.mindgarden.com/16-multifactor-leadership-quest ionnaire\#horizontalTab6; accessed 29th November 2019).
} 
The MLQ is used frequently as an early 'diagnostic' part of a wider leadership development programme. These programmes vary greatly in duration and cost: those offered by business schools often comprise one or more one-to-two week block courses spread over several months, while corporate programmes may last just a few days. ${ }^{14}$

We have described the most commonly used 360-degree instrument, outlined how it is used in practice and provided statistics that show, despite the evidence challenging its credibility, that these psychometric tools are very widely used. However, our distinctive focus and contribution in this paper is not on the technical strengths or weaknesses of these tools but on their claim to produce ethical leaders. We turn next to a Foucauldian analysis of the 360-degree tool, to develop insights into what putative leaders may experience when they respond to expectations that they subject themselves to its measurement.

\section{The Subject of the Transformational Leader and the MLQ's Moral Framework}

The subjectivating potential of the 360-degree process and instrument on leaders emerges through being asked to focus attention on themselves and how they act and through subjecting themselves to an examination devised by 'experts' who claim to know precisely what person they must become to be a good leader. The instrument's desired leader subject takes a precise, prescribed form against which users must measure (confess of) themselves. As noted earlier, the ideal transformational leaders' form is implicitly raced, gendered and classed, thereby sanctioning and reproducing systemic inequalities. Aspiring transformational leaders must discipline and (con)form themselves within this discourse of the truth of leadership. They are required to engage in the panoptic process of self-discipline, internalising an encircling gaze that requires adherence with the standards of leadership prescribed. The data from individual assessments, meanwhile, collated, analysed and compared against a wider data pool, manages the 'conduct' of the leader population. However, individuals may (or should) seek to use this knowledge about themselves to engage in processes of self-formation. Within Foucault's terms, this can only be ethical if leaders' question and critique the expectations under which they are placed.

Bass and colleagues proclaim the MLQ's ethics, contending that individuals who uncritically conform with the 'moral truths' of their recommendations, who work

\footnotetext{
${ }^{14}$ See, for illustrative examples: https://www.exed.hbs.edu/leadership -development/; or https://catapult.co.nz/developing-leaders/catapultleadership-programme/
}

on themselves to achieve its prescribed standards, become 'good' leaders (Bass 1999; Bass and Avolio 1994; Bass and Steidlmeier 1999). There is no scope or invitation to engage in critique in this process: its 'truths' cannot be questioned. In receiving feedback leaders must not challenge but accept it and, henceforth, change their very being to accord with the tool's prescriptions. Conformity is the goal and how success is conceived. Consequently, resistance in any form is likely taken as evidence not of an ethical practice of selfconstitution but, rather, failure to engage with and achieve the required standards. The instrument's constitutive focus is, thus, production of obedient, compliant leaders who are rendered unable to ethically exercise agency as regards their selves and their actions.

Turning to consider the specific characteristics of the subject sought via the prescriptions of transformational leadership and its off-shoot, the MLQ, and the moral codes which inform such prescriptions, we first offer a brief reminder of our analytic method, as drawn from Foucault's understanding of processes of subjectification. From this, we understand that selves are both constituted and self-constituting (Foucault 1977, 1986, 1990). Such processes occur within historically contingent power/knowledge discourses and other normalizing apparatuses, resulting in accounts of idealized selves that are articulated in scientific and/or normative discourses and which prescribe modes of being with which actual subjects are encouraged and expected to conform.

These prescriptions constitute moral codes which we refer to in what follows as 'norms' and which, for Foucault, contrast with the domain of ethics, the latter relying on practices of self-making that involve critical questioning of the self and of what is deemed moral. Our focus here is the specific characteristics of the leader-subject sought by transformational leadership, via these psychometric instruments, and what these expectations reveal regarding the implicit moral code upon which they depend. Table 1 summarises the theory's and associated tool's major factors: we now analyse each element in turn.

Idealised influence prescribes a (leader) self that possesses charisma, confidence, a sense of mission and personal power, who is focussed on "higher-order ideals and ethics" (Antonakis et al. 2003, p. 264) and who instils "pride, respect and trust" in followers (Van Knippenberg and Sitkin 2013, p. 5). Such a self, it follows, must see, know and experience itself as more capable, driven, insightful and influential than others. This positions followers as leaders' inferiors. Followers are understood, implicitly, as vessels lacking 'pride', 'trust' and 'respect' until 'instilled' in them by leaders. Consequently, leader selves are predicated on followers' inadequacies, suggesting an underpinning ethos of inequality. Followers, envisaged as targets for leader interventions, seemingly have no right to give consent or claim autonomy, 
suggesting an underpinning theory of paternalism at best and domination at worst. This core idea-that non-leaders are fundamentally deficient—-seemingly justifies leaders' rights and powers to seek to 'transform' followers' very being and is embedded in transformational leadership theory and, thus, the MLQ. The MLQ's first moral norm then is: believe in your own superiority and followers' deficiencies. This, however, also disciplines leaders: given no opportunity to voice concerns or offer critique these are the parameters within and through which they must constitute themselves as leaders. Failure to achieve the specified standards marks them as defective, needing to work on and improve themselves. Hence the second moral norm: your superiority rests on your unquestioning compliance with what has been prescribed as constituting leadership.

The next dimension, inspirational motivation, requires a self who can "energize" followers by promoting a positive view of the future, emphasizing ambitious goals and high standards of performance, "projecting an idealized vision" and communicating confidence in its achievement (Antonakis et al. 2003, pp. 264-245). Leaders should be and are future-focussed. Followers are presumed preoccupied with today's mundane realities and to be incapable of imagining/ envisioning and creating a bright, shining future. Leaders, meanwhile, must envisage and strive for nothing less than an 'ideal' future.

Not only is this unrealistic, impractical and immodest, it also requires leaders to be grandiose and narcissistic (Alvesson 2013; Alvesson and Kärreman 2016; Tourish 2013). In propounding 'prozac leadership' (Collinson 2012), such overly positive views necessitate avoidance or misrepresentation of realities that are always less-than-ideal. It requires that the leader simply wills an ideal future into being; the sheer potency of their vision and personality alone are the sources of such transformational change. Contesting the kind of future envisaged appears unacceptable: it is assumed to have merit without question. Realistic objections, alternative futures, participative/collaborative/collegiate processes and sheer practicalities have no part in leaders' capacity for inspirational motivation. Followers are, once again, marked and constituted by their lack of what leaders possess. In sum, scoring high on this factor indicates a leader self, thereby invoking a third moral norm of egotistical selfindulgence and fantasy, carried out in the name of inspirational motivation.

The next major element, intellectual stimulation, requires leaders to appeal to followers' "sense of logic and analysis" and to encourage them to "think creatively" and "find solutions to difficult problems" (Antonakis et al. 2003, p. 264), while heeding followers' ideas. This appears promising. Note, however, that intellectual stimulation must be encouraged with no recourse whatsoever to the ultimate objectives of this creativity; that is, critical analysis is not to be encouraged. Secondly, any attention paid to followers' ideas arises within the 'constitutional' context of the leadermanager/follower-worker relationship, where inequalities of power and dialectical tensions are ever present (Collinson 2005, 2006). Thirdly, this feature of the self resides alongside other features prescribed by the tool and does not automatically prevail over them but, rather, interacts with them in complex and dynamic ways. This suggests a moral norm requiring a focus on limited forms of logical analysis and creative thought, restricted to very narrow parameters: there must be no questioning of the organization's objectives. This norm is thus ultimately one of obedience bordering on obeisance, sought by leaders motivated by the fantasies, narcissism and hubris provoked within them as they seek to embody idealized influence and inspirational motivation.

The final transformational element is individualised consideration. This entails a self engaged in "advising, supporting and paying attention to the individual needs of followers, and thus allowing them to develop and self-actualize" (Antonakis et al. 2003, p, 265). Whilst this may imply a caring leader self, a closer look suggests it is a paternalistic self that (a) knows best what 'followers' need for their selfactualisation and (b) locates their betterment solely within organizational requirements for productive, disciplined staff. It not only equates managerial authority with moral authority while undermining followers' autonomy in self-constitution, it simultaneously seeks to eliminate leaders' potential for resistance, autonomy and ethical practices. Under the guise of individualised consideration leaders must embody a moral in which care must be practised - but as an act of domination, including of oneself, that prevents and inhibits critique or resistance.

Turning now to the transactional and non-leadership aspects of contingent reward, management by exception and laissez-faire leadership, these assume a managerial context for leadership. Contingent reward requires leaders to both clarify "role and task requirements" and offer "material or psychological rewards", provided "contractual obligations" are met (Antonakis et al. 2003, p. 265). Management by exception has active and passive forms. It requires leaders' engagement in pre-emptive monitoring to maintain standards or, alternatively, intervention only after problems have arisen. The final factor, laissez-faire leadership, essentially articulates what leaders should not do or be. It positions effective leaders as those who make decisions, accept responsibility and use their authority (Antonakis et al. 2003).

The inclusion of factors seemingly so dissonant with the transformational elements serves to remind leaders that their duty is not to their followers but to an organization whose needs outweigh everything else. If leaders were tempted, through practising individualised consideration, inspirational motivation, etc., to put followers' needs before those of profit or efficiency, then these managerialist 
elements serve to remind them of their duty of fealty to the organization.

While popular interpretation, following Zaleznik (1977), understands that 'leaders' and 'managers' are fundamentally different beings, transformational leadership theory and its associated 360-degree-instrument, the MLQ, instils these managerial expectations within the selves of leaders, anchoring them with rights and duties to direct, reward and punish others who fail to meet expectations. The composite moral norm that leaders and followers alike must follow is that of unquestioning, uncritical commitment to organizational demands to maximise profits and/or efficiency. Indeed, Bass and Avolio claim consistently that transformational leaders achieve superior organizational outcomes through gaining greater employee commitment, involvement, loyalty and enlightened management, all of which are deemed to be fundamental to longer term improvements (see, for example, Bass and Avolio 1994, p. 7). Clearly such norms and behaviours serve the interests of business owners but, simultaneously, conflate these with the interests of other stakeholders.

With the addition of these transactional elements, the moral norms that govern leader-selves are made evident. Using the MLQ as our illustrative case for examining 360-degree psychometric tools we show its design and application takes for granted the goodness of whatever organizations do. Acquiescence is sought, critique quashed and docile compliance within a narrowly drawn set of normative practices and behaviours are encouraged. Alternative ways of thinking, doing and practising leadership are closed off.

These 360-degree instruments are completed by many thousands of people across the world annually. Tomorrow's leaders are invited to explore, develop understanding of, and then work on themselves through a very narrow and instrumental lens. Those who comply constitute themselves as docile, obedient and disciplined managerial subjects charged with constituting others as similarly unquestioning and compliant. Overall, these approaches are located within what we call capitalism's negative morality: the desire to call into being docile leader-manager subjects whose function is to call into being docile worker-followers. The latter must understand themselves as constituted as fault-ridden in ways that only their leader-manager can correct. The ultimate purpose is serving organizations' demands for ever-greater productivity. In this arrangement the Auschwitz 'promise', that work will set you free, finds expression.

Our analysis of the MLQ concludes with a brief account of the historically contingent ways in which aspiring leaders have come to be expected to think about themselves by reference to its prescriptions. Accordingly, its emergence is, in Foucauldian terms, understood best as not simply resulting from the accumulation of knowledge through the objective methods of managerial and psychological science but, rather, as constituting a strategic response to the problematization
(Foucault 1977, 1978) of 'change' as a focal issue requiring leader attention, along with an increased focus on emotion, values and culture as key levers for leader influence on organizational performance (Alvesson and Kärreman 2016; Western 2007; Wilson 2016).

These concerns emerged within discourses of a crisis of confidence in American industry in the 1970s, the loss of power of traditional claims to authority and greater interest in the 'non-rationality' of 'human factors' in organizational theory and business education (Trethewey and Goodall 2007; Sinclair 2007; Wilson 2016). The framing of 'change', 'culture' and matters of employee motivation and engagement thus became central concerns for modern managerscum-leaders (Sinclair 2007; Western 2007; Wilson 2016).

The particular form that transformational leadership takes, meanwhile, is located in Western culture's long history of fascination with 'heroic', exciting, attractive and inspiring men, ideals now repackaged in the apparently objective language of leadership and organizational science (Gemmill and Oakley 1992; Spoelstra 2013; Wilson 2016). Understood in this way, transformational leadership is an historically-contingent, strategically-motivated discourse that privileges organizational elites, whose identity as 'leader' resides in offering bold visions and shaping workplace culture and employees' feelings. The 360-degree instrument is the tool designed to deliver such leaders: specifically, Mind Garden claims the "MLQ identifies the characteristics of a transformational leader" 15 and that feedback from a 360-degree assessment using the MLQ will "provide specific information" to a leader "to provide a basis for growth and change" 16 in order to become a transformational leader. However, drawing on Foucault we argue for caution in accepting such claims and practices uncritically.

The appeal of such devices resides in their alignment with wider discourses about the desirability and potency of leadership, especially its transformational form, amplified by its aura of scientific rigour. Such messages do have widespread appeal even though they are underpinned by assumptions that are biased against women, people of colour and those without access to the cultural and financial capital that goes with being middle class. However, given the near hegemonic influence of neoliberal capitalist ideology in many countries (Scharff 2015) the MLQ is well-positioned to have wide appeal at this historical juncture, due to its broad coherence, in form and purpose, with vast arrays of commercially lucrative self-making practices used by entrepreneurial subjects within neoliberal capitalism (Scharff 2015).

\footnotetext{
15 https://www.mindgarden.com/16-multifactor-leadership-quest ionnaire; accessed 29th November 2019).

16 https://www.mindgarden.com/16-multifactor-leadership-quest ionnaire\#horizontalTab6; accessed 29th November 2019).
} 


\section{Implications}

The morals encoded within transformational leadership and the MLQ are clear but highly problematic. They are illustrative of problems with heroic leader-centric models and their associated tools more generally. Consequently, we conclude by examining some of the implications arising from our analysis.

Discourses of leadership are currently so dominant their disappearance is difficult to envisage. As we have noted, practices claiming to offer self-development opportunities have wide-spread appeal under neoliberal capitalism. However, Foucault's late work offers a way forward. It articulates a practice of ethics involving technologies of the self and, substantively, care of the self, requiring the self to work on itself to constitute itself as an ethical agent (Foucault 2008, 2010). This self, although mired within multiple apparatuses of governmentality and accompanying expert discourses, "question[s] truth on its effects of power and power on its discourses of truth" (cited in Taylor 2011b, p. 179). That is, the self learns to recognise and resist the moral but unethical practices that weigh upon it. Parrhesia, or courageous speech, is practised, questioning that which is normalised (Foucault 2008). In forming for itself a new relation to power, truth and knowledge, the ethical self becomes better placed to "navigate power relations in ways that mediate against and attempt to minimize constraints while maximizing capacities" (Taylor 2011b, p. 180).

This Foucauldian ethics is the domain where freedom from domination (including and especially domination by normative morals) and new practices of the self as an ethical being are sought. Such ethical practices require, first, critical reflection about which aspects of the self need ethical development; second, subjecting to critique the merits of the actions, ways of being, attitudes and beliefs prescribed by discourses of power/knowledge; third, enacting techniques of self-discipline and self-mastery to bring the self into accordance with its desired ethical position; and, finally, identifying for the self the ideal to which that self aspires (Foucault 1986; Ladkin 2018; Robinson n.d.).

Foucault thus offers not only the means by which to interrogate disciplinary power but also insights into how to resist it. His work offers the intellectual means for engagement with, and critique of, demands placed upon selves to conform with pervasive and normalized expectations that we become organisationally desirable subjects. In our own teaching, we ask students to explore why they have been required to think about leadership in heroic, transformational terms, to understand the history of such notions, to recognise these expectations as disciplining mechanisms and identify how they may generate greater freedom for themselves and their colleagues through resisting the subjectivation imperative of 360-degree instruments. To enable this, we expose students to critically informed work that disrupts and challenges the dominant discourse (e.g. Carroll et al. 2018, 2019) and solicit their engagement in critical reflective practice (Cunliffe 2004).

A recent example saw MBA students asked to read two critically informed articles addressing issues of leader identity, ethics and self-making (Sinclair 2011; Ladkin 2018) and then to explore a range of critically reflective questions about the expectations placed on leaders, how these related to their own sense of self and what strategies of resistance or distancing from those expectations would be useful in strengthening their sense of self. These teaching practices engage us in fostering self-making that is not merely a reflection of dominant norms. These pedagogical practices are consistent with the academic tradition of speaking truth to power, which aids in vouchsafing their legitimate use even for untenured or junior faculty.

This move towards greater freedom is located in Foucault's understanding of ethics as comprising the work of the self on itself in order to craft itself as an ethical agent. For Foucault, critique is also the route through which ethics emerge. Questioning the ideas through which our very subjectivity arises transforms the self. Foucault understood well that acts of critique designed to gain critical distance from established authority implies risking 'the leader's' formation as an identifiable subject (1990). In other words, through assisting our students to recognise processes of resistance and practices of self-constitution we may facilitate a process that ultimately takes the concept and the practice of leadership in a more ethical direction.

\section{Conclusion}

The heroic school of leadership thought insists, not always explicitly, that its models contribute to ethical leadership practices. One of the most influential of these, transformational leadership theory (Bass 1985), has developed a methodology for translating its recommendations into practice. Its major instrument, the MLQ, is a 360-degree psychometric tool that has been translated into numerous languages. ${ }^{17}$ suggesting that many, many thousands of managers around the world have been inculcated into constituting forms of the self that, we argue, are unethical.

The MLQ is but one of many 360-degree instruments. Our Foucauldian analysis suggests that rather than producing ethical leaders such apparatuses produce docile, disciplined programme-followers whose potential for ethical agency is

\footnotetext{
17 https://www.mindgarden.com/16-multifactor-leadership-quest ionnaire\#horizontalTab6; accessed 29th November 2019.
} 
occluded. In the case of the MLQ, it facilitates the development of leaders who (wrongly) see themselves as superior beings charged with the task of producing docile, disciplined followers. We cannot expect that this critique will lead to the demise of leadership development courses and the application of 360-degree instruments soon. But what we can, perhaps should, do is use such critiques when educating our students, current and future managers to encourage them to resist the seductive powers of leadership.

\section{Compliance with Ethical Standards}

Conflict of interest The authors declare that they have no conflict of interest.

Ethical Approval We can confirm that there are no human or animal participants involved in this research paper. We have followed the required ethical standards throughout.

Open Access This article is licensed under a Creative Commons Attribution 4.0 International License, which permits use, sharing, adaptation, distribution and reproduction in any medium or format, as long as you give appropriate credit to the original author(s) and the source, provide a link to the Creative Commons licence, and indicate if changes were made. The images or other third party material in this article are included in the article's Creative Commons licence, unless indicated otherwise in a credit line to the material. If material is not included in the article's Creative Commons licence and your intended use is not permitted by statutory regulation or exceeds the permitted use, you will need to obtain permission directly from the copyright holder. To view a copy of this licence, visit http://creativecommons.org/licenses/by/4.0/.

\section{References}

Adler, N. J. (2006). The arts \& leadership: Now that we can do anything, what will we do? Academy of Management Learning \& Education, 5(4), 486-499.

Alvesson, M. (1996). Leadership studies: From procedure and abstraction to reflexivity and situation. The Leadership Quarterly, 7(4), 455-485.

Alvesson, M. (2013). The triumph of emptiness: Consumption, higher education, and work organization. Oxford: Oxford University Press.

Alvesson, M., \& Kärreman, D. (2016). Intellectual failure and ideological success in organization studies: The case of transformational leadership. Journal of Management Inquiry, 25(2), 139-152.

Alvesson, M., \& Sveningsson, S. (2003). The great disappearing act: Difficulties in doing "leadership". The Leadership Quarterly, 14(3), 359-381.

Antonakis, J., Avolio, B. J., \& Sivasubramaniam, N. (2003). Context and leadership: An examination of the nine-factor full-range leadership theory using the Multifactor Leadership Questionnaire. The Leadership Quarterly, 14(3), 261-295.

Antonakis, J., \& House, R. J. (2002). An analysis of the full-range leadership theory: The way forward. In B. J. Avolio \& F. J. Yammarino (Eds.), Transformational and Charismatic Leadership: The Road Ahead (pp. 3-34). Amsterdam: JAI Press.
Atwater, L., \& Waldman, D. (1998). 360 Degree feedback and leadership development. Leadership Quarterly, 9(4), 423-426.

Avery, G. C. (2004). Understanding leadership: Paradigms and cases. London: Sage.

Avolio, B. J., Avey, J. B., \& Quisenberry, D. (2010). Estimating return on leadership development investment. The Leadership Quarterly, 21(4), 633-644.

Avolio, B. J., \& Bass, B. M. (1991). The full range leadership development programs: Basic and advanced manuals. Binghampton, NY: Avolio \& Associates.

Avolio, B. J., \& Bass, B. M. (1995). Individual consideration viewed at multiple levels of analysis: A multi-level framework for examining the diffusion of transformational leadership. The Leadership Quarterly, 6(2), 199-221.

Avolio, B. J., Bass, B. M., \& Jung, D. I. (1999a). Re-examining the components of transformational and transactional leadership using the Multifactor Leadership Questionnaire. Journal of Occupational and Organizational Psychology, 72(4), 441-462.

Avolio, B. J., Bass, B. M., \& Jung, D. I. (1999b). Re-examining the components of transformational and transactional leadership using the Multifactor Leadership Questionnaire. Journal of Occupational and Organizational Psychology, 72, 441-462.

Avolio, B. J., \& Gardner, W. L. (2005). Authentic leadership development: Getting to the root of positive forms of leadership. The Leadership Quarterly, 16(3), 315-338.

Avolio, B. J., \& Luthans, F. (2003). Authentic leadership: A positive developmental approach. In K. S. Cameron, J. E. Dutton, \& R. E. Quinn (Eds.), Positive organizational scholarship (pp. 241-261) San Francisco, CA: Berrett-Koehler.

Bass, B. M. (1985). Leadership and performance beyond expectations. New York: Free Press.

Bass, B. M. (1995). Theory of transformational leadership redux. The Leadership Quarterly, 6(4), 463-478.

Bass, B. M. (1999). Two decades of research and development in transformational leadership. European Journal of Work \& Organizational Psychology, 8(1), 9-32.

Bass, B. M., \& Avolio, B. J. (1994). Transformational leadership and organizational culture. International Journal of Public Administration, 17(3-4), 541-554.

Bass, B. M., \& Riggio, R. (2006). Transformational leadership. Hillsdale, NJ: Lawrence Erlbaum.

Bass, B. M., \& Steidlmeier, P. (1999). Ethics, character, and authentic transformational leadership behaviour. The Leadership Quarterly, 10(2), 181-217.

Bolden, R., Hawkins, B., Gosling, J., \& Taylor, S. (2011). Exploring leadership: Individual, organizational and societal perspectives. Oxford: Oxford University Press.

Bradford, M., \& Leberman, S. (2017). BeWeDo: A dynamic approach to leadership development for co-creation. Leadership, 15(1), $58-80$.

Braun, S., Peus, C., Weisweiler, S., \& Frey, D. (2013). Transformational leadership, job satisfaction, and team performance: A multilevel mediation model of trust. The Leadership Quarterly, 24(1), 270-283.

Calás, M. B., \& Smircich, L. (1991). Voicing seduction to silence leadership. Organization Studies, 12(4), 567-602.

Carroll, B., Firth, J., \& Wilson, S. (Eds.). (2018). After leadership. Abingdon: Routledge.

Carroll, B., Ford, J. K., \& Taylor, S. (Eds.). (2019). Leadership: Contemporary critical perspectives (2nd ed.). London: Sage.

Carroll, B., Levy, L., \& Richmond, D. (2008). Leadership as practice: Challenging the competency paradigm. Leadership, 4(4), 363-379.

Carroll, B., \& Nicholson, H. (2014). Resistance and struggle in leadership development. Human Relations, 67(11), 1413-1436. 
Ciulla, J. B. (1995). Leadership ethics: Mapping the terrain. Business Ethics Quarterly, 5(1), 5-28.

Ciulla, J. B. (2013). Searching for Mandela: The saint as a sinner who keeps on trying. In D. Ladkin \& C. Spiller (Eds.), Authentic leadership: Clashes, convergences and coalescences (pp. 152-175). Cheltenham: Edward Elgar.

Collinson, D. L. (2003). Identities and Insecurities: Selves at Work. Organization, 10(3), 527-547.

Collinson, D. (2005). Dialectics of leadership. Human Relations, 58(11), 1419-1442.

Collinson, D. (2006). Rethinking folllowership: A post-structuralist analysis of follower identities. The Leadership Quarterly, 17(1), 179-189.

Collinson, D. L. (2011). Critical leadership studies. In A. Bryman, D. L. Collinson, B. Jackson, \& M. Uhl-Bien (Eds.), The Sage handbook of leadership (pp. 181-193). London: Sage.

Collinson, D. (2012). Prozac leadership and the limits of positive thinking. Leadership, 8(2), 87-107.

Collinson, D. L., \& Tourish, D. (2015). Teaching leadership critically: new directions for leadership pedagogy. Academy of Management Learning and Education, 14(4), 576-594.

Crane, A., Knights, D., \& Starkey, K. (2008). The conditions of our freedom: Foucault, organization and ethics. Business Ethics Quarterly, 18(3), 299-320.

Crevani, L., Lindgren, M., \& Packendorff, J. (2010). Leadership, not leaders: On the study of leadership as practices and interactions. Scandinavian Journal of Management, 26, 77-86.

Cunliffe, A. (2004). On becoming a critically reflexive practitioner. Journal of Management Education, 28(4), 407-426.

Day, D. V. (2001). Leadership development: A review in context. The Leadership Quarterly, 11(4), 581-613.

Day, D. V. (2011). Leadership development. In A. Bryman, D. L. Collinson, B. Jackson, \& M. Uhl-Bien (Eds.), The Sage handbook of leadership (pp. 37-50). London: Sage.

Day, D. V., Fleenor, J. W., Atwater, L. E., Sturm, R. E., \& McKee, R. A. (2014). Advances in leader and leadership development: A review of 25 years of research and theory. The Leadership Quarterly, 25(1), 63-82.

Delaney, H., \& Spoelstra, S. (2019). Transformational leadership: secularized theology? In B. Carroll, J. Ford, \& S. Taylor (Eds.), Leadership: Contemporary Critical Perspectives (2nd ed., pp. 93-111). London: Sage.

Diochon, P. F., \& Nizet, J. (2019). Re-embedding leadership development: Exploring power dynamics to understand the insensitivity of coaching programs to organizational contexts. Leadership, 15(5), 603-620.

Eagly, A. H., \& Chin, J. L. (2010). Diversity and leadership in a changing world. American Psychologist, 65(3), 216-224.

Edwards, G., Elliott, C., Iszatt-White, M., \& Schedlitzki, D. (2013). Critical and alternative approaches to leadership learning and development. Management Learning, 44(1), 3-10.

Facteau, C. L., Facteau, J. D., Schoel, L. C., Russell, J. E. A., \& Poteet, M. L. (1998). Reactions of leaders to 360-degree feedback from subordinates and peers. The Leadership Quarterly, 9(4), 27-448.

Fleenor, J. W., Smither, J. W., Atwater, L. E., Braddy, P. W., \& Sturm, R. E. (2010). Self-other rating agreement in leadership: A review. The Leadership Quarterly, 21(6), 1005-1034.

Ford, J., \& Harding, N. (2007). Move over management: We are all leaders now. Management Learning, 38(5), 475-493.

Ford, J., \& Harding, N. (2011). The impossibility of the 'true self' of authentic leadership. Leadership, 7(4), 463-479.

Ford, J., \& Harding, N. (2018). Followers in Leadership Theory: Fiction, Fantasy and Illusion. Leadership., 14(1), 3-24.
Ford, J., Harding, N., \& Learmonth, M. (2008). Leadership as identity: Constructions and deconstructions. Basingstoke: Palgrave Macmillan.

Foucault, M. (1977). Discipline and punish: The birth of the prison (A. Sheridan, Trans.). London: Penguin Books.

Foucault, M. (1978). The history of sexuality volume 1: The will to knowledge (R. Hurley. Trans.). New York: Random House.

Foucault, M. (1982). The subject and power. In H. L. Dreyfus \& P. Rabinow (Eds.), Michel Foucault: Beyond structuralism and hermeneutics (pp. 208-228). Chicago: University of Chicago Press.

Foucault, M. (1986). The history of sexuality volume 3: The care of the self (R. Hurley, Trans). London: Penguin.

Foucault, M. (1989). The birth of the clinic (A. Sheridan Smith, Trans). London: Routledge.

Foucault, M. (1990). The history of sexuality volume 2: The use of pleasure (R. Hurley, Trans.). New York: Vintage.

Foucault, M. (2008). The courage of truth (The government of self and others II): Lectures at the College de France, 1983-1984 (G. Burchell, Trans). Basingstoke, Hampshire.

Foucault, M. (2010). The Government of Self and Others: Lectures at the College de France, 1982-1983. Translated by G. Burchell. Basingstoke, Hampshire: Palgrave Macmillan.

Gabel, L., Harker, K., \& Sanders, E. S. (2011). Leadership development: What's evaluation got to do with it? International Journal of Training and Development, 65(3), 58-60.

Gagnon, S., \& Collinson, D. (2014). Rethinking global leadership development programmes: The interrelated significance of power, context and identity. Organization Studies, 35(5), 645-670.

Gagnon, S., Vough, H. C., \& Nickerson, R. (2012). Learning to lead, unscripted: Developing affiliative leadership through improvisational theatre. Human Resource Development Review, 11, 299-325.

Gemmill, G. R., \& Oakley, J. (1992). Leadership: An alienating social myth? Human Relations, 45(2), 113-129.

Ghoshal, S. (2005). Bad management theories are destroying good management practices. Academy of Management Learning \& Education, 4(1), 75-91.

Gordon, C. (1991). Governmental rationality: An introduction. In G. Burchell, C. Gordon, \& P. Miller (Eds.), The Foucault effect: Studies in governmentality (pp. 1-52). London: Harvester Wheatsheaf.

Grint, K., Smolović-Jones, O., \& Holt, C. (2016). What is leadership: Person, result, position, purpose or process, or all or none of these? In J. Storey, J.-L. Hartley, P. t' Hart, \& D. Ulrich (Eds.), The Routledge companion to leadership (pp. 3-20). New York: Routledge.

Harrison, R. (2017). Leadership, leadership development and all that jazz. Leadership, 13(1), 81-99.

Hooijberg, R., \& Choi, J. (2000). Which leadership roles matter to whom? An examination of Rater effects on perceptions of effectiveness. The Leadership Quarterly, 11(3), 341-364.

Huczynski, A., \& Buchanan, D. (2006). Organizational behaviour. New York: Prentice-Hall.

Hunter, S. T., Bedell-Avers, K. E., \& Mumford, M. D. (2007). The typical leadership study: Assumptions, implications, and potential remedies. The Leadership Quarterly, 18(5), 435-446.

Jackson, B., \& Parry, K. (2011). A very short, fairly interesting and reasonably cheap book about studying leadership (2nd ed.). London: Sage.

Jeyaraman, M. M., Qadar, S. M. Z., Wierzbowski, A., Farshidfar, F., Lys, J., Dickson, G., et al. (2018). Return on investment in healthcare leadership development programs. Leadership in Health Services, 31(1), 77-97. 
Kellerman, B. (2004). Bad leadership: What it is, how it happens, why it matters. Boston: Harvard Business School Press.

Kellerman, B. (2018). Professionalizing leadership. Oxford, UK: Oxford University Press.

Kolb, R. (1987). Teaching the text. The commonplace method in sixteenth century Lutheran biblical commentary. Bibliothèque d'Humanisme Renaissance, 49(3), 571-585.

Ladkin, D. M. (2008). Leading beautifully: How mastery, congruence and purpose create the aesthetic of embodied leadership practice. The Leadership Quarterly, 19(1), 31-41.

Ladkin, D. (2018). Self constitution as the foundation for leading ethically: A Foucauldian possibility. Business Ethics Quarterly, 28(3), 301-323.

Larsson, M., Holmberg, R., \& Kempster, S. (2019). 'It's the organization that is wrong': Exploring disengagement from organizations through leadership development. Leadership. https://doi. org/10.1177/1742715019879306.

Liu, H. (2020). Redeeming Leadership: An anti-racist feminist intervention. Bristol: Bristol University Press.

Liu, H., \& Baker, C. (2016). White Knights: Leadership as the heroicisation of whiteness. Leadership, 12(4), 420-448.

Lowe, K. B., Kroeck, K. G., \& Sivasubramaniam, N. (1996). Effectiveness correlates of transformational and transactional leadership: A meta-analytic review of the MLQ literature. The Leadership Quarterly, 7(3), 385-425.

Lugar, C. W., Garrett-Scott, S., Novicevic, M. M., Popoola, I. T., Humphreys, J., \& Mills, A. J. (2019). The historical emergence of intersectional leadership: Maggie Lena Walker and the independent order of St Luke. Leadership. https://doi.org/10.1177/17427 15019870375.

Mabey, C. (2013). Leadership development in organizations: Multiple discourses and diverse practice. International Journal of Management Reviews, 15(4), 359-380.

Mabey, C., \& Mayrhofer, W. (Eds.). (2015). Developing leadership: Questions business schools don't ask. Los Angeles, CA: Sage.

Markham, S. E., Markham, I. S., \& Smith, J. W. (2015). At the crux of dyadic leadership: Self-other agreement of leaders and direct reports-Analysing 360-degree feedback. The Leadership Quarterly, 26(6), 958-977.

May, T. (2011). Foucault's conception of freedom. In D. Taylor (Ed.), Michel Foucault: Key concepts (pp. 71-84). Durham, UK: Acumen.

Meindl, J. R., Ehrlich, S. B., \& Dukerich, J. M. (1985). The romance of leadership. Administrative Science Quarterly, 30(1), 78-102.

Mennicken, A., \& Miller, P. (2014). Michel Foucault and the administering of lives. In P. S. Alder, P. Du Gay, G. Morgan, \& M. Reed (Eds.), The Oxford handbook of sociology, social theory, and organization studies (pp. 11-38). Oxford: Oxford University Press.

Mintzberg, H. (2003). Managers, not MBA's: A hard look at the soft practice of managing and management development. San Francisco, CA: Berett-Koehler.

Nicholson, H., \& Carroll, B. (2013). Identity undoing and power relations in leadership development. Human Relations, 66(9), $1225-1248$

Northouse, P. (2013). Leadership theory and practice (6th ed.). Thousand Oaks, CA: Sage.

Pinnington, A. (2011). Leadership development: Applying the same leadership theories and development practices to different contexts? Leadership, 7(3), 335-365.

Probert, J., \& James, K. T. (2011). Leadership development: Crisis, opportunities and the leadership concept. Leadership, 7(2), 137-150.
Robinson, B. (n.d.). Michel Foucault: Ethics. In J. Fieser \& B. Dowden (Eds.), Internet encyclopedia of philosophy. https://www.iep.utm. edu/fouc-eth/.

Rowold, J. (2005). Multifactor leadership questionnaire. Psychometric properties of the German translation by Jens Rowold. Redwood City, CA: Mind Garden.

Scharff, C. (2015). The psychic life of neoliberalism: Mapping the contours of entrepreneurial subjectivity. Theory, Culture \& Society, 33(6), 107-122.

Sinclair, A. (1998). Doing leadership differently: Gender, power and sexuality in a changing business culture. Carlton, VIC: Melbourne University Publishing.

Sinclair, A. (2007). Leadership for the disillusioned: Moving beyond myths and heroes to leading that liberates. Crows Nest, NSW: Allen \& Unwin.

Sinclair, A. (2011). Being leaders: Identities and identity work in leadership. In A. Bryman, D. Collinson, K. Grint, B. Jackson, \& M. Uhl-Bien (Eds.), The Sage handbook of leadership (pp. 508-517). Los Angeles: Sage.

Spoelstra, S. (2013). Leadership studies: Out of business. In J. Lemmergaard \& S. M. Muhr (Eds.), Critical perspectives on leadership: Emotion, toxicity and dysfunction (pp. 171-182). Cheltenham: Edward Elgar.

Stead, V., \& Elliott, C. (2009). Women's leadership. Basingstoke: Palgrave Macmillan.

Subramony, M., Segers, J., Chadwick, C., \& Shyamsunder, A. (2018). Leadership development practice bundles and organizational performance: The mediating role of human capital and social capital. Journal of Business Research, 83, 120-129.

Sutherland, I. (2013). Arts-based methods in leadership development: Affording aesthetic workspaces, reflexivity and memories with momentum. Management Learning, 44(1), 25-43.

Taylor, D. (2011a). Introduction: Power, freedom and subjectivity. In D. Taylor (Ed.), Michel Foucault: Key concepts (pp. 1-12). Durham, UK: Acumen.

Taylor, D. (2011b). Practices of the self. In D. Taylor (Ed.), Michael Foucault: Key concepts (pp. 173-186). Durham, UK: Acumen.

Taylor, S. S., \& Ladkin, D. M. (2009). Understanding arts-based methods in managerial development. Academy of Management Learning \& Education, 8(1), 55-69.

Tourish, D. (2013). The dark side of transformational leadership: A critical perspective. London: Routledge.

Tourish, D., Craig, R., \& Amernic, J. (2010). Transformational leadership education and agency perspectives in business school pedagogy: A marriage of inconvenience? British Journal of Management, 21(1), 40-59.

Trethewey, A., \& Goodall Jnr, H. L. (2007). Leadership reconsidered as historical subject: Sketches from the Cold War to Post-9/11. Leadership, 3(4), 457-477.

Uhl-Bien, M. (2006). Relational leadership theory: Exploring the social processes of leadership and organizing. The Leadership Quarterly, 17(6), 654-676.

van Knippenberg, D., \& Sitkin, S. B. (2013). A critical assessment of charismatic-Transformational leadership research: Back to the drawing board? Academy of Management Annals, 7(1), 1-60.

Wang, X.-H., \& Howell, J. M. (2012). A multilevel study of transformational leadership, identification, and follower outcomes. The Leadership Quarterly, 23(5), 775-790.

Warech, M. A., Smithers, J. W., Reilly, R. R., Millsap, R. E., \& Reilly, S. P. (1998). Self-monitoring and 360-degree ratings. The Leadership Quarterly, 9(4), 449-473.

Western, S. (2007). Leadership: A critical text. London: Sage.

Whaley, A., \& Gillis, W. E. (2018). Leadership development programs for health care middle managers: An exploration of the top 
management team member perspective. Health Care Management Review, 43(1), 79-89.

Wilson, S. (2016). Thinking differently about leadership: A critical history of leadership studies. Cheltenham, UK: Edward Elgar.

Wong, C. I. A., Spence-Laschinger, H. K., \& Cummings, G. G. (2010). Authentic leadership and nurses' voice behaviour and perceptions of care quality. Journal of Nursing Management, 18(8), 889-900.
Zaleznik, A. (1977). Managers and leaders: Are they different? Harvard Business Review, 55(5), 67-80.

Publisher's Note Springer Nature remains neutral with regard to jurisdictional claims in published maps and institutional affiliations. 